\title{
PENERAPAN MODEL THINK TALK WRITE UNTUK MENINGKATKAN KETERAMPILAN MENULIS BAGI SISWA SEKOLAH MENENGAH PERTAMA
}

\author{
Mesterianti Hartati $^{1}$, Mai Yuliastri Simarmata ${ }^{2}$, Selly Firtawati ${ }^{3}$ \\ 1,2,3 Program Studi Pendidikan Bahasa dan Sastra Indonesia IKIP PGRI Pontianak \\ Jalan Ampera Nomor 88 Pontianak \\ 'e-mail: mesterianti.ikippgriptk@gmail.com
}

\begin{abstract}
Abstrak
Penelitian bertujuan untuk mengetahui dan mendapatkan informasi secara jelas dan objektif mengenai peningkatan keterampilan menulis teks berita dengan penerapan model cooperative learning tipe think talk write pada siswa kelas VIII Sekolah Menengah Pertama Negeri 1 Suhaid Kabupaten Kapuas Hulu. Penelitian menggunakan metode tindakan dengan bentuk penelitian tindakan kelas. Untuk objek penelitian adalah siswa kelas VIII A SMP Negeri 1 Suhaid Kabupaten Kapuas Hulu yang jumlahnya 24 orang dan 1 orang guru Bahasa Indonesia. Teknik pengumpul data yang digunakan adalah observasi langsung, komunikasi langsung, pengukuran, dan studi dokumenter. Teknik analisis data menggunakan statistik deskriptif komparatif. Hasil dari penelitian diketahui bahwa dalam proses pembelajaran menjadi lebih aktif dari sebelum penerapan model, sementara dari hasil pembelajaran terdapat peningkatan dari sebelum menggunakan model Think Talk Write hingga sesudah menggunakannya. Peningkatan tersebut terlihat dari persentase pembelajaran dengan ketercapaian indikator kinerja pada saat pra siklus yaitu $29,17 \%$ menjadi $91,67 \%$ di siklus 2 , terlihat peningkatan tersebut hingga $62,5 \%$.
\end{abstract}

Kata Kunci: keterampilan menulis, teks berita, tipe think talk write.

\begin{abstract}
This study aimed at finding out and getting information clearly and objectively about improving news text writing skills by applying the model of cooperative learning think talk write at the class VIII Suhaid 1 Junior High School 1 Kapuas Hulu District. The study used action methods, with a form of classroom action research. For the object of research was students of class VIII A of SMP Negeri 1 Suhaid in Kapuas Hulu Regency which consisted of 24 students and 1 teacher. Data collection techniques used in this study was direct observation, direct communication, measurement, and documentary study. Data analysis technique used in this study was classroom action research with comparative descriptive statistical technique. The results of this study showed that the learning process becomes more active than before the application of a model, moreover, from the learning outcomes there was an increase of up to $62 \%$ from the results of writing pre-cycle news text to the second cycle.
\end{abstract}

Keywords: writing skills, news text, type think talk write.

\section{PENDAHULUAN}

Keterampilan menulis merupakan salah satu dari empat keterampilan berbahasa yang mempunyai peranan penting dalam kehidupan manusia. Dengan menulis, seseorang dapat mengungkapkan pikiran dan gagasan untuk mencapai 
maksud dan tujuannya. Akhadiah (2009), mengungkapkan bahwa menulis berarti mengorganisasikan gagasan secara sistematik serta mengungkapkan secara tersurat. Sedangkan menurut Dalman (2015), menulis merupakan suatu kegiatan komunikasi berupa penyampaian pesan (informasi) secara tertulis kepada pihak lain dengan menggunakan bahasa tulis sebagai alat atau medianya.

Slamet (2008), menyatakan bahwa menulis adalah pengungkapan ide, pengetahuan, ilmu, dan pengalaman hidup seseorang dalam bahasa tulis. Dengan demikian, menulis diperlukan adanya suatu bentuk ekspresi gagasan yang berkesinambungan dan mempunyai urutan logis dengan menggunakan kosa kata dan tata bahasa tertentu atau kaidah bahasa yang digunakan sehingga dapat menggambarkan atau dapat menyajikan informasi yang diekspresikan secara jelas. Namun, banyak siswa yang mengeluh tidak bisa menulis dengan baik disebabkan kurangnya kosakata yang dimiliki siswa dan menulis dianggap sebagai beban yang berat karena kegiatan menulis membutuhkan banyak tenaga dan waktu serta perhatian yang sungguh-sungguh.

Salah satu materi pembelajaran menulis di sekolah adalah materi menulis teks berita. Menurut Barus (2010), berita adalah segala laporan mengenai peristiwa, kejadian, gagasan, fakta yang menarik perhatiandan penting untuk disampaikan atau dimuat dalam media massa agar diketahui atau menjadi kesadaran umum. Sedangkan menurut Chaer (2010), berita merupakan suatu peristiwa atau kejadian di dalam masyarakat, lalu kejadian atau peristiwa tersebut diulangi dalam bentuk kata-kata yang disiarkan secara tertulis dalam media tulis (surat kabar, majalah, dan lainnya) atau dalam media suara (radio, dan lainnya), atau juga dalam media suara dan gambar (televisi). Dari pendapat tersebut, disimpulkan bahwa teks berita adalah naskah berita yang berisi fakta mengenai kejadian peristiwa yang hangat, menarik atau penting bagi sebagian besar masyarakat yang bisa disampaikan melalui media berkala seperti surat kabar, radio, televisi atau media internet.

Berdasarkan hasil wawancara dan observasi yang dilakukan peneliti dengan guru bahasa Indonesia kelas VIII SMP Negeri 1 Suhaid Kabupaten Kapuas Hulu dengan Nila Hermiyati, S.Pd., diperoleh beberapa masalah yang dihadapi guru 
dalam proses belajar, khususnya materi menulis teks berita. Masalahnya siswa masih kurang dalam menulis terutama teks berita. Hal tersebut dapat dibuktikan dari perolehan nilai menulis teks berita siswa dari 24 siswa, hanya 7 siswa yang mencapai nilai standar indikator kinerja yaitu 75, sedangkan 17 siswa masih mencapai nilai di bawah KKM. Hanya 29,17\% sampai standar belajar untuk kelas tersebut, sedangkan yang belum sampai standar 70,83\%. Hal tersebut terjadi pada siswa kelas VIII A.

Peneliti memilih siswa kelas VIII A semester II dilandasi beberapa alasan berdasarkan wawancara dengan guru dan siswa, terdapat beberapa kendala yang dihadapi guru dan siswa dalam proses pembelajaran, diantaranya: (1) Kurangnya pengetahuan siswa terhadap menulis; (2) Kurangnya pengetahuan guru dalam pengembangan model pembelajaran; (3) Masih rendahnya kemampuan siswa dalam menulis teks berita serta kurangnya partisipasi siswa dalam mengikuti pembelajaran sastra khususnya dalam menulis teks berita karena sebagian besar siswa menganggap pembelajaran sastra kurang penting; dan (4) Hasil belajar siswa tentang materi menulis teks berita masih rendah.

Beberapa hal yang menjadi kendala sulitnya mahasiswa dalam menulis teks berita dikarenakan siswa kesulitan dalam menuangkan pikiran ke dalam bentuk tertulis. Siswa juga kesulitan dalam memperoleh ide tulisan (kesulitan dalam bernalar). Siswa juga mengalami kesulitan dalam menyusun atau menggunakan bahasa sehingga terbentuk teks berita. Sesuai dengan pendapat Chaer (2010), penggunaan bahasa dalam berita jika dirumuskan lebih ringkas, bahasa jurnalistik harus menerapkan tiga prinsip dalam menggunakan bahasa yaitu hemat kata, tepat makna, dan menarik. Kesulitan siswa penulisan teks berita dikarenakan siswa sulit menemukan kata yang tepat serta menarik. Siswa juga sulit dalam menentukan pokok-pokok berita.

Dalam menulis teks berita ada enam aspek pokok yang dijadikan kriteria penilaian, yaitu: (1) Kelengkapan unsur-unsur berita $(5 \mathrm{~W}+1 \mathrm{H})$; (2) Keruntutan pemaparan (isi berita urut dan jelas); (3) Penggunaan kalimat singkat dan jelas; (4) Kosakata yang digunakan adalah kosakata yang baku; (5) Kemenarikan judul; dan (6) Ketepatan penggunaan EYD dalam berita (Depdiknas, 2003). Menurut 
Djurat (Wijana dan Rohmadi, 2011), yang mejadi unsur berita meliputi pokok berita yang dapat dijawab menggunakan pertanyaan: apa, siapa, mengapa, kapan, di mana, dan bagaimana serta aspek keruntutan pemaparan, penggunaan kalimat, kosakata, dan ketepatan ejaan. Pada penelitian yang dilakukan, hasil kerja siswa dinilai dari kelengkapan unsur beritanya.

Pemilihan model pembelajaran yang tepat akan membantu berhasilnya pembelajaran di kelas. Oleh karenanya, model pembelajaran yang akan dilakukan dengan menggunakan model cooperative learning tipe TTW (Think Talk Write) tepat untuk mengembangkan keterampilan pembelajaran menulis. Model pembelajaran TTW digunakan untuk membantu siswa agar lebih aktif dan produktif. Menurut Trianto (2003), TTW adalah suatu tipe model kooperatif untuk melatih keterampilan siswa dalam menalar. Model TTW pada dasarnya dibangun melalui berpikir, berbicara, dan menulis. Alur kemajuan model kooperatif tipe TTW dimulai dari keterlibatan siswa dalam berpikir atau berdialog dengan dirinya sendiri setelah proses mengamati. Selanjutnya berdiskusi dan membagi ide dengan temannya melalui diskusi. Sehingga pada akhirnya siswa dapat menulis hasil pemikirannya.

Alasan peneliti mengambil model cooperative learning tipe TTW: pertama, karena model pembelajaran TTW sangat sesuai dengan materi menulis teks berita; kedua, saat melakukan observasi pada pelajaran bahasa Indonesia tentang materi menulis teks berita guru hanya menggunakan metode ceramah. Model cooperative learning tipe TTW merupakan suatu model yang mengutamakan adanya kerja sama, yakni kerja sama antarsiswa dalam kelompok untuk mencapai tujuan pembelajaran. Metode TTW juga akan mengharuskan siswa untuk bernalar. Sesuai dengan permasalahan yang telah diungkapkan sebelumnya bahwa siswa mengalami kesulitan dalam mengembangkan tulisan dalam bentuk tulisan. Sehingga model TTW dianggap tepat karena menurut Sugiarti, dkk. (2014), TTW suatu model pembelajaran kooperatif yang dapat mengoptimalkan proses pembelajaran guna meningkatkan keterampilan menulis bahasa Indonesia. 
Model TTW pada dasarnya dibangun melalui berpikir, berbicara, dan menulis. Pembelajaran kooperatif dengan model TTW terdiri dari tiga tahap kegitan, yaitu: pertama, berpikir (think). Siswa secara individu memikirkan kemungkinan jawaban atau metode penyelesaian, membuat catatan kecil mengenai ide-ide yang terdapat dalam suatu bacaan, dan hal yang tidak dipahami. Langkah kedua, berbicara (talk). Peserta didik dilatih mengkomunikasikan pokok bahasan dengan anggota kelompoknya. Ketiga, menulis (write). Menulis penyelesaian masalah yang telah dibahas. Alur kemajuan model kooperatif tipe dimulai dari keterlibatan siswa dalam berpikir atau berdialog dengan dirinya sendiri setelah proses mengamati. Selanjutnya berdiskusi dan membagi ide dengan temannya melalui diskusi. Sehingga pada akhirnya siswa dapat menulis hasil pemikirannya.

Dalam pembelajaran kooperatif tipe TTW, salah satu langkah penerapannya siswa diharuskan untuk mengeluarkan ide yang dimilikinya untuk kemudian membaginya dengan teman sekelompok untuk saling mendapat masukan dan motivasi. Siswa yang sebelumnya terbiasa bersikap pasif setelah menggunakan model pembelajaran berkelompok ini akan terpaksa berpartisipasi secara aktif agar bisa diterima oleh anggota kelompoknya (Priyanto dalam Wina, 2006).

TTW dianggap tepat untuk memperbaiki permasalahan yang ada berkenaan dengan materi menulis teks berita. Pelaksanaan prosedur model kooperatif tipe TTW dengan benar akan memungkinkan pendidik mengelola kelas dengan lebih efektif. Ada berbagai elemen yang merupakan ketentuan pokok dalam pembelajaran model kooperatif tipe TTW, yaitu: (1) Mengamati dengan seksama; (2) Menggali ide yang dimiliki; (3) Saling berbagi secara positif (positive sharing); (4) Interaksi tatap muka (face to face interaction); (5) Keterampilan mengembangkan ide yang dimiliki; dan (6) Keterampilan untuk menjalin hubungan antarpribadi atau keterampilan sosial. TTW lebih menekankan keterlibatan siswa secara penuh. Siswa diharuskan untuk bisa aktif dan produktif serta terampil dalam hal menulis. Guru hanya bersifat sebagai fasilitator. 
Peranan dan tugas guru dalam usaha mengefektifkan penggunaan model pembelajaran kooperatif tipe TTW adalah mengajukan dan menyediakan tugas yang memungkinkan siswa terlibah secara aktif berpikir, mendorong dan menyimak dengan hati-hati ide-ide yang dikemukakan siswa secara lisan dan tertulis, mempertimbangkan dan memberi informasi terhadap apa yang digali siswa dalam diskusi, serta memonitori, menilai, dan mendorong siswa untuk berpartisipasi aktif (Silver dan Smith dalam Andriani, 2008). Melalui model cooperative learning tipe TTW yang diberikan oleh guru Bahasa Indonesia, setiap siswa termotivasi untuk aktif belajar sesuai dengan kemampuannya dan dapat menguasai setiap materi yang disampaikan oleh guru sehingga dapat meningkatkan hasil belajar siswa khususnya dalam menulis teks berita menjadi lebih baik serta dapat memberikan kekuatan berpikir pada siswa, dengan melakukan latihan-latihan, maka siswa akan mudah menjawab serta menyerap pertanyaan yang di dapatkannya.

Keberhasilan dari penerapan model TTW dapat dibuktikan oleh penelitian sebelumnya yang telah dilakukan oleh Sugiarti, dkk. (2014). Hasil dari penelitiannya terlihat ada perubahan nilai dari sebelum dilakukan model TTW dengan setelahnya. Perubahan nilai yang dimaksud adalah perubahan ke arah peningkatan dari hasil sebelumnya seperti yang telah dijelaskan. Karena yang menjadi salah satu langkah dari metode adalah mahasiswa diahruskan untuk berpikir kritis. Melalui berpikir kritis, siswa diharuskan memikirkan hal yang diperlukan dalam menulis berita. Selanjutnya hasil pemikiran tersebut dibahas bersama dengan peserta didik lainnya. Hasil pemikiran yang sudah matang dibuat dalam bentuk tulisan berupa teks berita.

\section{METODE}

Penelitian yang dilakukan merupakan penelitian tindakan. Alasan peneliti menggunakan metode penelitian tindakan adalah karena dalam proses penelitian, peneliti merancang dan melaksanakan suatu tindakan berupa upaya guru dalam meningkatkan keterampilan menulis teks berita melalui penerapan model cooperative learning tipe Think Talk Write pada mata pelajaran Bahasa Indonesia. 
Jenis penelitian yang digunakan adalah penelitian tindakan kelas (Classroom Action Research). Kemampuan yang ingin ditingkatkan dalam penelitian yang dilakukan adalah kemampuan menulis berita. Adapun usahan untuk meningkatkan hasil belajar siswa tersebut dengan cara menerapkan model pembelajaran inovatif, yaitu Think Talk Write.

Subjek penelitian adalah siswa kelas VIII A SMP Negeri 1 Suhaid Kabupaten Kapuas Hulu yang jumlahnya 24 orang dan 1 orang guru Bahasa Indonesia. Teknik pengumpul data yang digunakan adalah teknik observasi langsung, wawancara, pengukuran, dan studi dokumenter dengan alat pengumpul data berupa pedoman observasi, panduan wawancara, tes, dan dokumen yang berkaitan dengan administrasi pembelajaran.

Teknik analisis data yang digunakan dalam penelitian tindakan kelas adalah teknik analisis kritis dan analisis komparatif yang dilakukan dengan cara mendeskripsikan proses maupun hasil pembelajaran menulis teks berita yang menggunakan TTW, selanjutnya hasil tersebut dibandingkan dengan penerapan setiap siklusnya guna untuk melihat apakah terdapat peningkatan dari hasil pembelajaran setelah penelitian dilakukan.

\section{HASIL DAN PEMBAHASAN}

Kegiatan pembelajaran keterampilan menulis teks berita dengan model cooperative learning tipe TTW pada siswa kelas VIII A SMP Negeri 1 Suhaid Kabupaten Kapuas Hulu adalah hal yang baru. Pembelajaran prasiklus menggunakan metode pembelajaran koonvensional atau ceramah, sedangkan pembelajaran siklus I dan siklus II melalui model cooperative learning tipe TTW.

Aspek yang diteli dalam penelitian memfokuskan pada proses pembelajaran dan hasil pembelajaran menulis teks berita menggunakan metode TTW. Peningkatan proses belajar siswa diikuti peningkatan hasil belajar siswa kemudian juga diikuti dengan perubahan perilaku siswa ke arah yang positif.

\section{Proses Pembelajaran Model Cooperative Learning Tipe TTW}

Berdasarkan hasil observasi awal, diperoleh gambaran bahwa minat dan motivasi siswa dalam pembelajaran menulis teks berita masih rendah, siswa 
kurang tertarik dengan pembelajarannya. Hal tersebut merupakan akibat dari proses pembelajaran yang kurang memperhatikan keterlibatan siswa dalam pembelajaran. Dari hasil pengamatan awal diperoleh permasalahan sebagai berikut: (1) Pembelajaran masih bersifat konvensional yang masih terpusat pada guru; (2) Kemampuan menulis teks berita siswa belum memadai/cukup, nilai belum mencapai KKM; dan (3) Siswa tidak tertarik/bosan dengan pembelajaran menulis teks berita.

Guru masih menjadi pusat pembelajaran, akibatnya pembelajaran menjadi kurang kondusif dan kurang menyenangkan. Kondisi tersebut membawa dampak yang negatif terhadap keterampilan menulis teks berita. Guru harus mengubah paradigma dalam pembelajaran menulis teks berita sesuai dengan perkembangan zaman. Berdasarkan permasalahan tersebut tindakan yang telah dilakukan dalam penelitian adalah menggunakan model cooperative learning tipe TTW dalam menulis teks berita.

Model cooperative learning tipe TTW telah diterapkan dalam pembelajaran menulis teks berita melalui tindakan sebanyak dua siklus. Setiap siklus dilaksanakan dalam dua kali pertemuan. Berdasarkan hasil observasi dan hasil tes yang telah dilakukan dari siklus I sampai siklus II pembelajaran menulis teks berita mengalami peningkatan. Peningkatan mencakup peningkatan kualitas proses pembelajaran peningkatan keterampilan menulis teks berita siswa kelas VIII A SMP Negeri 1 Suhaid Kabupaten Kapuas Hulu.

Setelah diterapkannya model cooperative learning tipe TTW dalam pembelajaran menulis teks berita, maka selama berlangsungnya proses pembelajaran terasa lebih hidup dari pada sebelumnya. Tindakan-tindakan yang dilaksanakan dalam tiap siklus mampu meningkatkan kualitas pembelajaran dan hasil belajar siswa kelas VIII A SMP Negeri 1 Suhaid Kabupaten Kapuas Hulu. Hal tersebut dapat terlihat pada aspek-aspek berikut.

\section{Keaktifan siswa}

Keaktifan siswa dalam pembelajaran menulis teks berita mengalami peningkatan. Keaktifan siswa dalam proses pembelajaran menulis teks berita menjadi sangat penting sehingga harus dipahami oleh guru, bahwa guru harus 
menciptakan proses pembelajaran yang menempatkan siswa sebagai subjek dan guru tidak mendominasi dalam proses pembelajaran menulis teks berita. Keaktifan siswa pada pra siklus rata-rata 52,78\%, sedangkan keaktifan siswa pada siklus I rata-rata $66,67 \%$ pada pertemuan pertama sedangkan pada pertemuan kedua keaktifan siswa rata-rata 72,22\%, dan keaktifan siswa pada siklus II ratarata $86,11 \%$ pada pertemuan pertama sedangkan pada pertemuan kedua keaktifan siswa rata-rata $91,67 \%$.

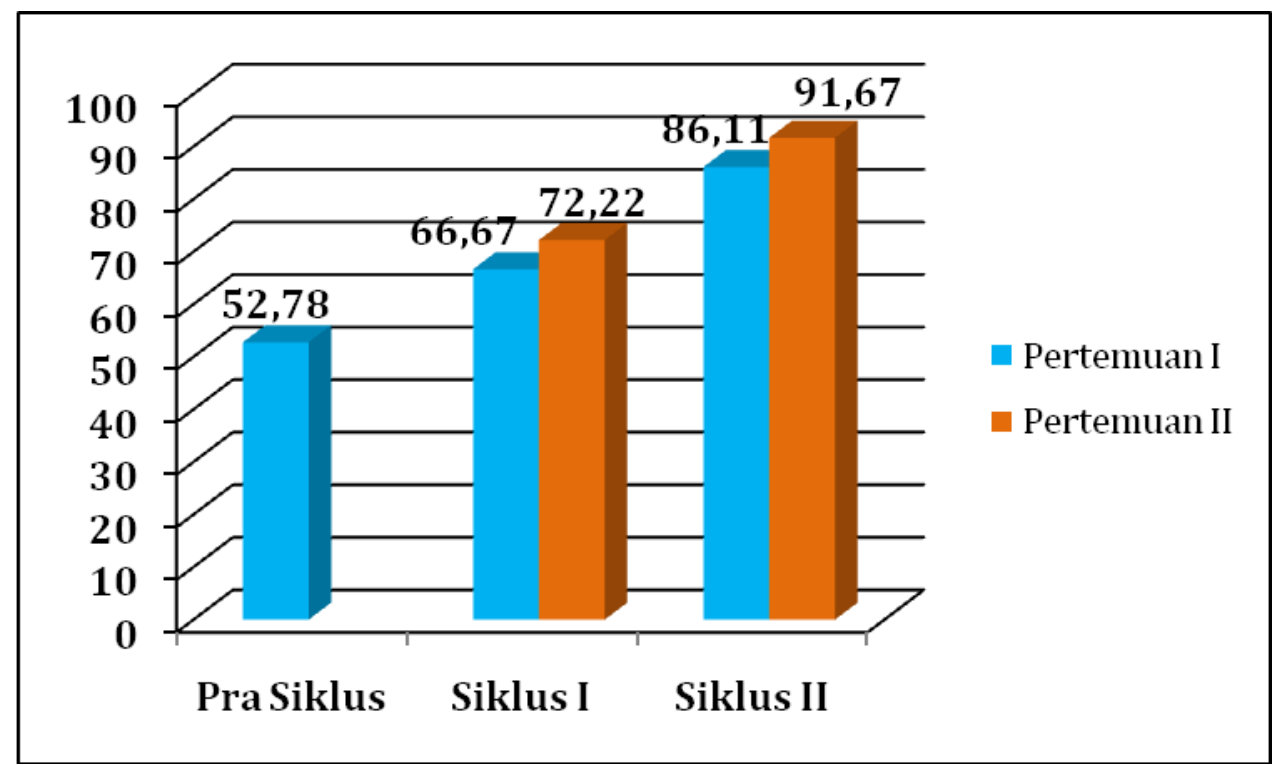

\section{Gambar 1 Keaktifan Siswa dalam Menulis Teks Berita SMP Negeri 1 Suhaid Kapubaten Kapuas Hulu}

\section{Minat dan motivasi siswa}

Sebelum diberikan tindakan, minat dan motivasi siswa kurang, setelah diberikan tindakan dengan menerapkan model cooperative learning tipe TTW dalam menulis teks berita, siswa tampak lebih berminat dan termotivasi mengikuti pembelajaran Bahasa Indonesia. Pemberian reward (penghargaan) berupa pujian bagi individu yang memperoleh point tertinggi mampu meningkatkan minat dan motivasi siswa lain.

\section{Keterampilan guru dalam mengelola kelas}

Kemampuan guru dalam mengelola kelas merupakan salah satu penentu keberhasilan proses pembelajaran. Guru yang profesional mempunyai ciri-ciri: (1) Memiliki kepribadian yang matang dan berkembang; (2) Penggunaan ilmu yang 
kuat; (3) Keterampilan untuk membangkitkan peserta didik kepada sains dan teknologi; dan (4) Pengembangan profesi secara berkesinambungan.

Sebelum diberikan tindakan pembelajaran didominasi dengan metode ceramah. Dalam pembelajaran ketika guru menggunakan model cooperative learning tipe TTW pada saat menyampaikan materi menulis teks berita, guru dapat menciptakan suasana pembelajaran yang kondusif. Guru telah mampu membangkitkan minat, keaktifan, dan tangung jawab siswa. Guru aktif dalam memantau kinerja siswa dan menekankan kepada siswa bahwa siswa mempunyai tanggung jawab untuk memastikan setiap aspek yang dipelajari dapat diserap dengan baik. Guru memberi masukan atau penjelasan dengan cara bertanya atau menjawab pertanyaan yang diajukan siswa.

Kemampuan guru dalam mengelola kelas pada pra siklus rata-rata 53,95\%, sedangkan pada siklus I rata-rata 62,07\% pada pertemuan pertama sedangkan pada pertemuan kedua mencapai $67,24 \%$, dan pada siklus II rata-rata $72,41 \%$ pada pertemuan pertama sedangkan pada pertemuan kedua mencapai $82,76 \%$.

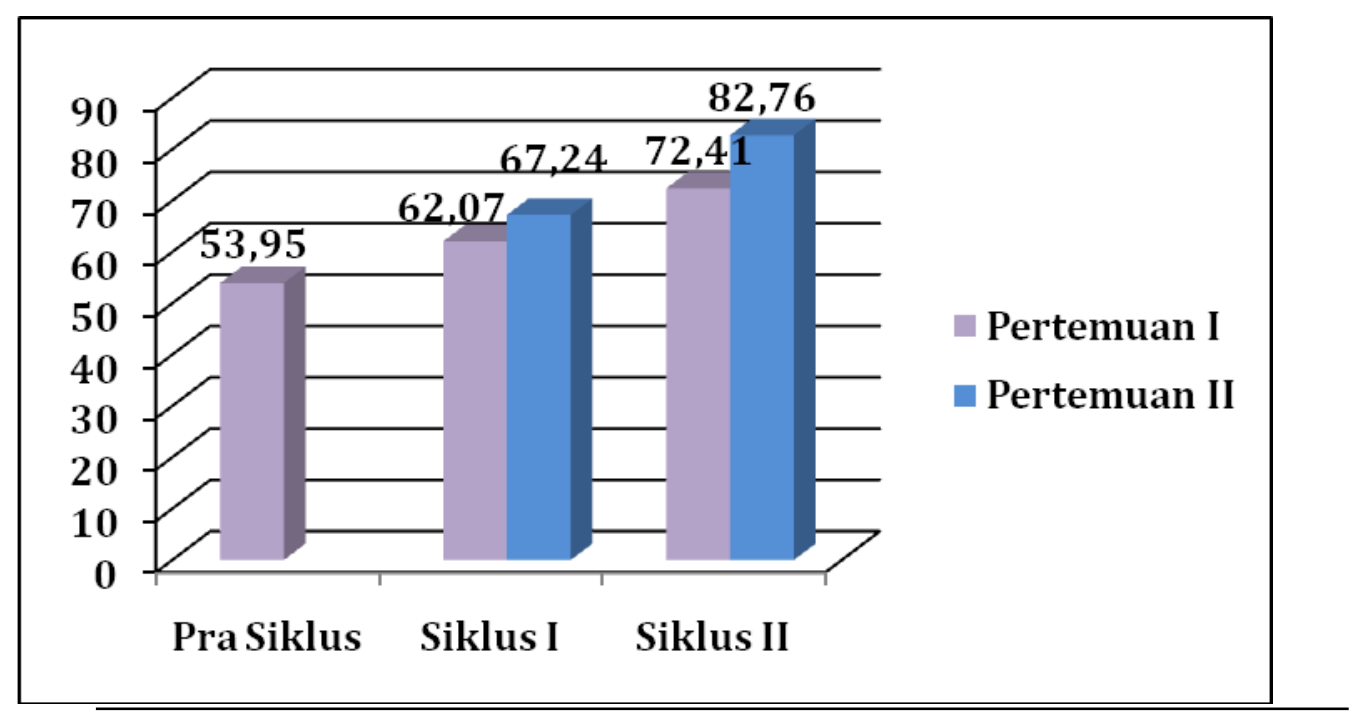

Gambar 2 Kemampuan Guru dalam Mengelola Kelas VIII A SMP Negeri 1 Suhaid Kapubaten Kapuas Hulu

\section{Hasil Belajar Siswa melalui Model Cooperative Learning Tipe TTW}

Hasil belajar siswa kelas VIIIA SMP Negeri 1 Suhaid Kabupaten Kapuas Hulu dalam penelitian dapat dilihat dari nilai tes keseluruhan. Hasil tes yang dinilai berdasarkan kelengkapan isi teks berita, keruntutan pemaparan, 
penggunaan kalimat, kosakata yang digunakan, kemenarikan judul, dan ketepatan pengunaan EYD.

Berdasarkan yang dilakukan oleh guru pada pra siklus masih belum dapat mengoptimalkan keterampilan siswa dalam menulis teks berita, hal tersebut dapat dilihat dari hasil tes pra siklus siswa yang berjumlah 24 orang memperoleh nilai mencapai standar sebanyak sebanyak 7 orang siswa dengan persentase ketercapaian indikator kinerja secara klasikal yaitu 29,17\% dan nilai rata-rata 64,125. Setelah dilakukan siklus I, siswa yang memperoleh nilai mencapai standar sebanyak 11 orang siswa dengan persentase ketercapaian indikator secara klasikal yaitu 45,83\% dan nilai rata-rata 71,63 dari 24 siswa yang mengikuti tes siklus I. Artinya terjadi peningkatan $16,66 \%$ (4 orang siswa) pada siklus I walau belum mencapai 75 dari kriteria Indikator kinerja. Selanjutnya pada siklus II, siswa yang memperoleh nilai lebih dari 75 sebanyak 22 orang siswa dengan persentase ketercapaian indikator secara klasikal yaitu $91,67 \%$ dan nilai rata-rata 80,79 dari 24 siswa yang mengikuti tes siklus II.

Tabel 1 Hasil Penilaian Tes Formatif

\begin{tabular}{cccc}
\hline Keterangan & Pra Siklus & Siklus I & Siklus II \\
\hline $\begin{array}{c}\text { Ketercapaian } \\
\text { Standar Indikator }\end{array}$ & 7 & 11 & 22 \\
$\begin{array}{c}\text { Kinerja } \\
\text { Belum Tercapai }\end{array}$ & 17 & 13 & 2 \\
Nilai Terendah & 52 & 54 & 69 \\
Nilai Tertinggi & 82 & 84 & 92 \\
$\Sigma \bar{\Sigma}$ & $1539 / 24$ & $1719 / 24$ & $1939 / 24$ \\
$\bar{N}$ & 64,125 & 71,63 & 80,79 \\
$\overline{\boldsymbol{x}}$ & $\mathbf{2 9 , 1 7 \%}$ & $\mathbf{4 5 , 8 3 \%}$ & $\mathbf{9 1 , 6 7 \%}$ \\
\hline $\begin{array}{c}\text { Ketercapaian } \\
\text { Indikator Kinerja } \\
\text { Klasikal }\end{array}$ & & & \\
\hline
\end{tabular}

Melalui penerapan model cooperative learning tipe TTW, hasil belajar siswa mengalami peningkatan yang cukup berarti, hal tersebut dapat dilihat dari hasil tes siklus I dan siklus II. Artinya terjadi peningkatan 45,84\% (11 orang siswa) pada siklus II dan sudah mencapai nilai kriteria indikator kinerja. Sebelum diberikan tindakan (pra siklus) hasil belajar siswa kelas VIII A secara klasikal hanya 29,17\%, setelah diberikan tindakan (siklus I maka hasil belajar belum 
mencapai indikator kinerja yang telah ditetapkan) diperoleh hanya 45,83\%. Setelah diberikan tindakan yang sama pada siklus II, hasil belajar siswa menjadi $91,67 \%$ dari standar indikator keberhasilan yang telah ditentukan.

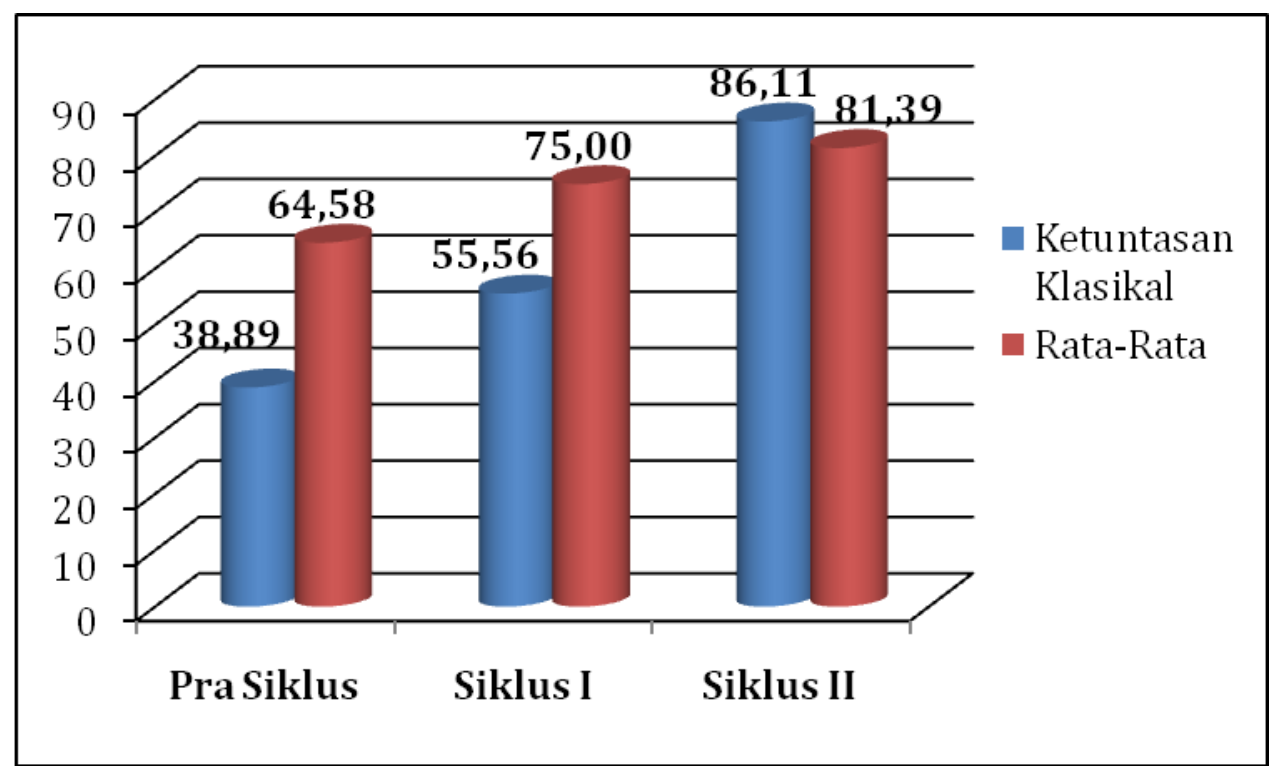

\section{Gambar 3 Hasil Belajar Siswa Kelas VIII A SMP Negeri 1 Suhaid Kapubaten Kapuas Hulu}

Berdasarkan Gambar 3, dapat disimpulkan bahwa dengan tindakan melalui model cooperative learning tipe TTW dapat meningkatkan keterampilan menulis teks berita pada siswa di kelas VIII A SMP Negeri 1 Suhaid Kabupaten Kapuas Hulu.

Berdasarkan dari hasil penelitian dari tiap siklus baik dari segi keaktifan siswa dan peran guru dalam mengelola kelas menunjukan peningkatan. Melihat dari nilai rata-rata, dapat dikatakan nilai siswa sudah melebihi KKM. Guru dan peneliti sepakat tidak melanjutkan ke siklus III karena tujuan penelitian sudah tercapai, yaitu meningkatkan menulis teks berita dengan menggunakan model cooperative learning tipe TTW pada siswa kelas VIII A Negeri 1 Suhaid Kabupaten Kapuas Hulu.

\section{SIMPULAN}

Berdasarkan hasil analisis data dan pembahasan, secara umum dapat disimpulkan bahwa dengan menggunakan model cooperative learning tipe Think 
Talk Write dapat meningkatkan keterampilan menulis teks berita siswa kelas VIII A SMP Negeri 1 Suhaid Kabupaten Kapuas Hulu. Selanjutnya, beberapa kesimpulan sebagai berikut: (1) Pada proses pembelajaran yang menerapkan model TTW yang diperoleh melalui hasil lembar observasi, terjadi perubahan pola tingkah laku siswa. Siswa menjadi lebih aktif dan antusias dalam pembelajaran. Siswa tampak lebih dapat berpikir kritis dan mennuangkan ide pikirannya ke dalam tulisan; (2) Adanya peningkatan keterampilan menulis teks berita siswa kelas VIII A SMP Negeri 1 Suhaid Kabupaten Kapuas Hulu setelah mengikuti pembelajaran menulis teks berita melalui model cooperative learning tipe TTW. Hasil tes prasiklus diperoleh nilai rata-rata 64,125 dengan ketercapaian indikator kinerja yaitu 29,17\%, sedangkan siklus I diperoleh nilai rata-rata kelas 71,63 dengan ketercapaian indikator kinerja yaitu 45,83\% (11 siswa yang mencapai standar) dan pada siklus II nilai rata-rata siswa mencapai 80,79 dengan ketercapaian indikator kinerja yaitu 91,67\% (22 siswa yang mencapai indikator). Hal tersebut menunjukkan peningkatan dari prasiklus sampai pada siklus II sebesar $62,50 \%$.

\section{DAFTAR PUSTAKA}

Akhadiah, dkk. 2009. Pembinaan Kemampuan Menulis Bahasa Indonesia. Jakarta: Erlangga.

Arikunto, S. dkk. 2015. Penelitian Tindakan Kelas. Jakarta: Bumi Aksara.

Barus, S. W. 2010. Jurnalistik: Petunjuk Teknis Menulis Berita. Jakarta: Erlangga. Chaer, A. 2010. Bahasa Jurnalistik. Jakarta: Rineka Cipta.

Dalman. 2015. Keterampilan Menulis. Jakarta: PT Raja Grafindo Persada.

Depdiknas. Undang-Undang Republik Indonesia No. 20 Tahun 2003, Tentang Sistem Pendidikan Nasional, Bandung: Citra Utama.

Haryati, N. 2018. Peningkatan Aktivitas Belajar dan Kemampuan Mengidentifikasi Unsur Intrinsik Teks Drama dalam Pembelajaran Bahasa Indonesia melalui Metode Pembelajaran Kooperatif Model Think Talk Write bagi Siswa Kelas VIII A SMP Murni 1 Surakarta Semester 1 Tahun Pelajaran 2016/2017.Jurnal Pendidikan Konvergensi, 24(5).

Sugiarti, N. L. P. Y., Putra, I. K. A., \& Abadi, I. B. G. S. 2014. Pengaruh Model Pembelajaran TTW (Think Talk Write) Berbantuan Media Gambar Berseri terhadap Keterampilan Menulis Bahasa Indonesia Siswa Kelas V SD Gugus 1 Kecamatan Kediri, Tabanan Tahun Ajaran 2013/2014. Jurnal Mimbar PGSD Undiksha, 2(1). 
Slamet , Y. 2008. Dasar-dasar Keterampilan Berbahasa Indonesia. Surakarta: UNS Press.

Trianto. 2003. Model-Model Pembelajaran Inovatif BerorientasiKonstruktivistik. Jakarta: Tim Prestasi Pustaka.

Wijana, I. D. P. \& Rohmadi, M. 2011. Analisis Wacana Pragmatik Kajian Teori dan Analisis. Surakarta: Yuma Pressindo. 